\title{
Yeni Kurumsalcı Bakış Açısından Düzenlemeler ve Düzenleyici Otoriteler
}

Regulations and Regulatory Authorities from the Perspective of New Institutionalism

Mete DİBO $^{1}$

Article Info

Article History:

Date Submitted: 21.05.2019

Date Accepted: 28.08 .2019

Jel Classification

B15, N40, P48

Keywords:

New Institutionalism,

Regulation,

Rational Choice

Institutionalism,

Historical Institutionalism,

Discursive Institutionalism
Abstract

One of the most important goals of economics is to develop policies to improve the economic performance. These policy proposals are effective in the emergence of economic theories. The differences in the policy proposals emerge as a factor that separates the theories from each other. Institutional economic approach as one of the relevant theories argues that the economic performance of countries depends largely on the institutional structures and processes adopted by policy makers. In this study the views of four approaches on the formation of economic and political structure are discussed. These approaches are rational choice institutionalism, sociological institutionalism, historical institutionalism and discursive institutionalism which are the types of new institutionalism.

\section{Özet}

Ekonomi biliminin önemli hedeflerinden birisi iktisadi etkinliği arttırmaya yönelik politikalar geliştirmektir. İktisadi teorilerin ortaya çıkışı da genel olarak bu politika önerileri doğrultusunda gerçekleşmektedir. Politika önerilerindeki farklılıklar ilgili teorileri birbirinden ayrıştıran bir etken olarak karşımıza çıkmaktadır. Kurumsal iktisadi yaklaşım da sözü edilen teorilerden birisidir ve ülkelerin ekonomik performansının büyük ölçüde politika yapıcılar tarafindan benimsenen kurumsal yapı ve işleyişlere bağlı olduğunu öne sürmektedir. Bu çalışma, yeni kurumsalcı yaklaşımın türleri olan rasyonel tercih kurumsalcılığı, sosyolojik kurumsalcılık, tarihsel kurumsalcılık ve söylemsel kurumsalcılık yaklaşımlarının, iktisadi ve politik yapının oluşumuna yönelik görüşlerine yer vermektedir.

\section{Giriş}

Kurumlar, insanlar arasındaki etkileşimi biçimlendiren ve insanlar tarafindan belirlenen kisitlamalardır. Douglass C. North, kurumların bir toplumda oynanan oyunun kurallarını

\footnotetext{
${ }^{1}$ Dr.Öğr.Üyesi, Hitit Üniversitesi, İktisadi ve İdari Bilimler Fakültesi, Maliye Bölümü, metedibo@hitit.edu.tr
} 
belirlediğini ifade etmektedir. Kurumlar, anayasa ve kanunlar gibi resmen oluşturulmuş veya zaman içerisinde evrimleşerek gelişim göstermiş olabilirler (North, 2010: 9). North’a göre kurumlar, kişiler arasındaki ilişkileri düzenlemektedir. Belirsizliklerin, nispi fiyat değişimleri ile işlem maliyetlerinin azaltılması ve mülkiyet haklarının tanımlanarak güvence altına alınması kurumlar aracılığıyla tesis edilebilmektedir. Böylece kurumlar, ülkelerin iktisadi performansları üzerinde belirleyici bir role sahip olmaktadırlar (Eroğlu, 2018: 175) Kurumlar, ekonomik yaşamda hangi alanlarda ne tür faaliyetlerin kimler tarafindan hangi sınırlar dâhilinde gerçekleştirilebileceğine karar verebilmektedirler.

Karar alıcılar, aşırı kısıtlamalar ya da olağan üstü serbestlikler tanıyan kuralları benimseyebilirler. Bu noktada ilgili kuralların belirli bir denge gözetilerek oluşturulması önem arz etmektedir. Dengenin nasıl kurulabileceğine ilişskin olarak geliştirilen farklı yaklaşımlar esas olarak devletin düzenleyici rolünün hangi boyutlarda kalması gerektiğine yönelik öneriler sunmaktadir.

Bireysel mülkiyet hakları - devlet sahipliğgi, serbestleşme - korumacılık, modern üretim - gelenekselcilik, tekelci yapı - rekabet, girişimcilikte yoğun bürokrasi - kolay yatırım olanakları gibi alternatif tercihler bir toplumun kurumsal yapısının inşasında önem arz etmektedir.

Oluşturulan kurumsal yap1 içerisinde üretim ve işlem maliyetlerinde, teknolojik gelişimde, mülkiyet haklarının korunmasında, belirsizliğin giderilmesinde vb. kaydedilen başarı oranında ülkelerin iktisadi performansları değişiklik gösterecektir. Çünkü burada bahsedilen hususlar yatırımcıların karar verme süreçlerini etkileme gücüne sahiptir.

Kurumsal yapı içerisinde gerçekleştirilen düzenlemelerin ortaya çıkaracağı etkilerin yeni kurumsalcı yaklaşım kapsamında ele alınması bu çalışmanın amacını oluşturmaktadır. İlgili amaç doğrultusunda çalışmada ilk olarak iki numaralı başlık altında eski ve yeni kurumsalcılık kavramlarına değinilerek bu yaklaşımlara katkı sağlayan teorisyenlerin görüşlerine yer verilmektedir. Ardından üç numaralı başlık altında yeni kurumsalcı yaklaşımın, düzenleyiciliğe ilişkin genel çerçevesi aktarılmaktadır. Çalışmanın daha sonraki başlıklarında ise yeni kurumsalcılığın alt türleri olan rasyonel tercih kurumsalcılığ 1 , sosyolojik kurumsalcılık, tarihsel kurumsalcılık ve söylemsel kurumsalcılık yaklaşımlarının düzenlemeler ile idari otoritelere dönük görüşleri ele alınmaktadır. 


\section{Eski Kurumsalcılık ve Yeni Kurumsalcılık}

Eski kurumsalcılık yaklaşımına ilişkin iki temel yaklaşımdan söz edilebilir. İlki Thorstein Veblen ve Veblen'in sistemini geliştirerek yeniden şekillendiren Clarence Ayres yaklaşımıdır. Bu yaklaşım, düşünmenin ve gerçekleştirmenin kurumsal ve teknolojik yolu olarak açıklanabilir. En geniş anlamda bu program yeni teknolojilerin kurumsal düzen üzerindeki etkisini ve kazanılmış çıkarlar ile gerçekleşmiş olan sosyal sözleşmelerin bu tür bir değişime karşı nasıl direnç göstereceğini ele almaktadır (Rutherford, 1994: 1, 2).

İlgili yaklaşımda, bilimi de kapsayan teknoloji, modern toplumları ve belki de tüm toplumları şekillendiren dinamik bir güç olarak görülmektedir. Bu minvalde kurumsalcılığın, modern düşünceyle aynı çizgide olduğu görülmektedir. Batılı uygarlıklar büyük ölçüde bilim ve makineleşme süreciyle şekillenmiştir. Veblen, araç-gereç kullanımını, üretken ve insanlığın elde ettiği tüm başarıların altında yatan yaratıcı bir süreç olarak görmektedir (Ayres, 1951: 51).

Eski kurumsalcılığa yönelik ikinci temel yaklaşım ise John R. Commons ve Warren Samuels ile Allan Schmid'in çalışmalarına dayanmaktadır. Bu yaklaşım hukuk, mülkiyet hakları ve kuruluşlar, bunların gelişimleri ile yasal ve ekonomik güç üzerindeki etkileri, iktisadi işlemler ve gelirin dağılımı üzerinde durmaktadır. Burada kurumlar büyük ölçüde uyuşmazlıkların çözüm sürecinin resmi ve gayri resmi sonucu olarak görülmektedir. Başarı kriteri, kurumun uyuşmazlığa yol açmaksızın "makul bir değer” veya "uygulanabilir mütekabiliyet” üretip üretemeyeceğidir (Rutherford, 1994: 2).

Eski kurumsalcı yaklaşımın temsilcilerinden Schmid, kurumsal yapının ortaya çıkaracağ1 performansı değerlendirmek üzere bir yapı oluşturmuştur. Bu yapıda; ürün gruplar1 ve bunlarla ilişkili çıkar grupları, benimsenecek olan mülkiyet hakları yapısı ve buna göre elde edilecek sonuçlar (performans-uygulamadan hangi tarafın nasıl etkileneceği) belirtilmektedir. Örneğin hava kirliliğine yol açan bir faaliyetle ilgili olarak temiz havanın fabrikatör ve astım hastası arasındaki paylaşımı ele alalım. Temiz havanın kullanım hakkının astım hastasına verildiğini varsayalım. Bu durumunda fabrika sahibi astım hastasına havayı kirletebilmek için teklifte bulunabilir veya astım hastası kirleticiye dava açarak fabrikanın kapanmasına yol açabilir. Diğer taraftan doğrudan düzenlemelerle kirletme yasaklanabilir ve bu durumda hakların ticarete (alım-satıma) konu olması söz konusu değildir. Buradaki örnekte birbiriyle uyumsuz bir kullanım söz konusudur (Schmid, 1981: 77-78). 
Schmid ayrıca yüksek dışlama maliyetlerinin olduğu ve ölçek ekonomilerinin bulunduğu durumlarda da benimsenecek olan mülkiyet yapısının veya fiyatlama yönteminin farklı sonuçlar doğuracağını belirtmektedir. Faktör mülkiyetine sahip olunması durumunda üçüncü kişiler ilgili kaynağın kullanımından dışlanabilmektedir. Ancak dışlama maliyetleri çok yüksek olduğunda üçüncü kişileri ilgili kaynaktan dışlama hakk1 önemsiz bir hak haline gelebilmektedir. Bu durum bir örnek yardımıyla açıklanabilir. Bir hayvan sürüsünü avlamak üzere lisans satın alan bir avcı avlanma başarısını garantileyecektir. Fakat boş alana dağılmış olan hayvanlar, bu hakkı satın almayanlar için önemli firsatlar yaratmaktadır. Devlet, lisansa sahip olmayanların kullanımını önlemek üzere koruyucular istihdam edebilir. Bu durumda kanuni avlanma hakkına sahip avcılar sadece hayvanlar için değil aynı zamanda güvenlik için de ödeme yapacaklardır (Schmid, 1981: 82). Güvenlik maliyetinin çok yüksek düzeyde olmas1, mülkiyet haklarına sahip olmanın avantajını zayıflatmaktadır. Sonuç itibariyle Schimid, refah dağılımının belirlenmesinde mülkiyet haklarının kime verilmiş olduğunu bilmenin tek başına yeterli olmadığını öne sürmektedir. Doğru bir değerlendirme yapabilmek için ölçek ekonomilerinin, dışlama maliyetlerinin ve çıkar grubu farklılıklarının dikkate alınması gerektiğini belirtmektedir.

Yeni kurumsalcılık yaklaşımı ise 1960 ve 1970’lerde etkili olan davranışsal bakış açısına karşı bir tepki olarak ortaya çıkmıştır. Yeni Kurumsalcılık çatısı altında değerlendirilen yaklaşımların (rasyonel tercih, sosyolojik, tarihsel ve söylemsel kurumsalcılık) hepsi de kurumların sosyal ve politik sonuçlar üzerindeki rolünü ortaya koymayı amaçlamaktadır. Yeni Kurumsalcılık yaklaşımı ekonomiye ilişkin olarak mülkiyet hakları, kiralamalar ve rekabetçi seçim mekanizmaları üzerinde yoğunlaşmaktadır (Hall \& Taylor, 1996: 936) .

Örneğin yeni kurumsalcı iktisat yaklaşımının önemli temsilcilerinden olan Demsetz ve Alchian (1973), mülkiyet haklarının uygulanma şeklinin (ortak ve özel mülkiyetin) doğuracağ1 sonuçları tartışmışlardır. Çalışmalarında mülkiyet haklarına ilişkin görüşlerini avlanmaya ilişkin örnekle açıklamışlardır. Buna göre; özel mülkiyetin olmadığı bir durumunda hayvanları avlayarak bunlar üzerinde hak sahibi olunabilirken, özel mülkiyetin varlığı halinde hayvanların avlanması ihtiyacı doğmayacaktır. Böylece hayvanlara sahip olanlar bunları uygun bir şekilde yetiştireceklerdir. Eğer ortak mülkiyet sisteminde olduğu gibi hayvanları avlamak onlara sahip olmanın bir yolu olursa, gereğinden fazla avlanılması sonucunda bunun sosyal maliyeti yüksek 
olacaktır. Sonuç olarak kaynakların ortak mülkiyeti yerine özel mülkiyetin benimsenmesinin daha etkin sonuçlar doğuracağını belirtmektedirler (Alchian ve Demsetz, 1973: 22-23).

Yeni kurumsalcı yaklaşıma ilişkin olarak Olson (1982) ve Mueller (1989)'in rant kollama ve dağıtımsal koalisyon faaliyetlerini içeren kamu tercihi süreçleriyle ilgili çalışmalarından da bahsedilebilir (Olson ve Mueller'den aktaran Rutherford, 1994: 2). Bu yaklaşımlara göre çıkar gruplarının faaliyetleri üretim olanaklarını daraltmakla kalmamakta, normal büyüme sürecini de yavaşlatmaktadır. Çıkar gruplarının farklı derecelerde demokratik olma eğilimleri karar alma süreçlerini geciktirmektedir. Dolayısıyla değişikliklere cevap verme hızları düşüktür ve etki alanları dâhilindeki kurumların değişimlere cevap verme veya değişiklikleri uygulama hızlarını da sekteye uğratmaktadırlar. Ek olarak kurumlar toplumun küçük bir bölümünü temsil ediyorlarsa, toplum çıkarlarına yönelik büyük fedakârlıklarda bulunmayacaklardır. Bunun yerine toplumsal üretimden daha büyük pay alabilmek için mücadele ederek kendi üyelerinin çıkarlarına hizmet etmeyi tercih ederler. Dolayısıyla çıkar gruplarının ortadan kaldırıldığı veya kendi hedeflerine ulaşmalarının sınırlandırıldığı ülkelerde büyüme daha hızlı gerçekleşecektir (Olson, 1982: 43-44; Mueller, 2003: 555).

Yeni kurumsalcı yaklaşıma ilişkin olarak Coase $(1937)^{2}$ 'un işlem maliyetlerine yönelik çalışmalarından da söz edilebilir. Coase, takas (değişim, devir) işlemleri ile pazarlık maliyetlerinin düşük olması ve iyi belirlenmiş, devredilebilir niteliğe sahip mülkiyet haklarının bulunması durumunda kaynak kullanımıyla ilgili etkinlik sorununun olmayacağını ileri sürmektedir. Yani bu durumda piyasalar etkinsiz olmayacaktır. İşlem maliyetlerinden kasıt, hak ve yetkilerin devredilmesine ilişkin maliyetlerdir. $\mathrm{Bu}$ maliyetler ise çoğunlukla iletişim güçlükleri ile işleme konu hak ve yetkilerin belirsizliği gibi unsurlardan kaynaklanmaktadır (Coase'dan aktaran Alchian, 1979: 233). Coase, sözleşmelerin ve mübadele işlemlerinin piyasalar kullanılarak gerçekleştirilmesinin maliyetleri üzerine odaklanmıştır. Piyasayı kullanma maliyetleri, doğrudan otoritenin kullanım maliyetlerini aşmadığı sürece bu faaliyetler firma tarafindan gerçekleştirilecektir (Jensen \& Meckling, 1979: 170).

Neo-klasik kuram ya da Avusturya Okulu'na yakın olsun, yeni kurumsalcılara göre eski kurumsalc1lık teoriden yoksundur ve bireyselcilik yerine bütüncül bir eğilime sahiptir. Ek

\footnotetext{
${ }^{2}$ Sözü edilen çalışma, Economica dergisinde yayınlanmış olan 1937 tarihli "The Nature of the Firm” başlıklı çalışmadır.
} 
olarak eski kurumsalcıların rasyonel tercih yerine davranışçı çerçeveyi kullanmaları, temel meselenin ekonomikleştirme (tasarruf) olduğu üzerine vurgu yapılmasındaki başarısızlıkları ve kolektif karar alma süreci ile kurumsal tasarıma önem vererek kurumsal gelişimdeki istem dış1 ve evrimsel sürecin önemini göz ardı etmeleri de eleştirilmektedir. Buradan yola çıkarak eski kurumsalcılığı; betimsel ve anti formalist, bütüncül, davranışçı ve kollektivist olarak tanımlayabiliriz. Eski kurumsalcılar aynı zamanda bireyci refah kriterini reddederler ve daha müdahalecilerdir. Kurumsal başarısızlıkların giderilmesinde daha büyük kamu payının olması gerektiği görüşünü desteklemektedirler (Rutherford, 1994: 3-4).

Eski ve yeni kurumsalcılık yaklaşımlarının özelliklerine ilişkin olarak Powell ve Di Maggio'nun görüşlerine göre ise eski kurumsalcı yaklaşım eylemlerin sınırlandırılmış ancak yine de rasyonel olduğunu öne sürmektedir. Sınırlı rasyonellik, aktörlerin mükemmel bilgiye sahip olmadıklarını ve bunun yerine tatmin edici çözümler aradıklarını vurgulamaktadır (Fligstein, 1991: 315). Buna karşın yeni kurumsalcı görüş ise rasyonellik kavramını tamamen reddetmektedir. Yeni kurumsalcılığa göre, sınırlı da olsa, siyasi aktör veya gruplar bireysel çıkarlarının peşinden gitmektedirler (Koelble, 1995: 236-237).

\section{Düzenleyicilik ve Yeni Kurumsalcı Yaklaşım}

Düzenleyicilik hem ortaya çıkışında hem de uygulanmasında karar alıcıların, kamu kurumlarının, yasama ve yürütme organlarının, çıkar gruplarının, işletmelerin ve sivil toplum örgütlerinin faaliyetleri etkili olmaktadır (Carrigan ve Coglianese, 2011: 107, 108). Tarihsel kısıtlar, çıkar grupları arasındaki rekabet, değişen siyasi ve bürokratik tepkiler de düzenlemelerin uzun dönem etkisini şekillendirmektedir. Bir düzenlemenin en büyük etkisi siyasi çıkar gruplarına ve daha sonraki düzenlemelere yönelik sonuçlarına ilişkindir. Düzenlemeler sonucunda siyasi çıkar gruplarının, politik süreçlerin ve politik çıktıların başkalaşması söz konusu olabilir. Yeni düzenlemeler sonucunda organizasyon yapıları, sözleşme şekilleri ve mülkiyet hakları gibi unsurlarda da değişimler söz konusu olabilecektir. Bütün bu değişimler sonucunda toplumsal refah kayıplarının azalması veya artması söz konusu olabilecektir (Benham, 2008: 605).

Radikal liberalleşme ve deregülasyon politikaları uygulamalarında da refah kayıpları ortaya çıkabilmektedir. Örneğin Latin Amerika ülkelerinin 1980'li yıllarda yaşadıkları krizlerin bir benzerinin yaşanmaması amacıyla önerilen Washington Konsensüsü politikaları gelişmekte olan ülkeler için etkin sonuçlar doğurmamıştır (Rodrik’ten aktaran Karakurt, 2011: 37). Bu 
durum rasyonel ve etkin kurumların, özellikle de kamusal kurumların, aslında sağlıklı bir ekonomi ve daha da ötesinde sağlıklı bir ulusun oluşumunda hayati role sahip olduğuna yönelik yeni bir fikir birliği oluşturmuştur. Bunun bir sonucu olarak yoksul ülkelerin daha müreffeh ve istikrarlı bir geleceğe sahip olmalarını sağlamak üzere rehberlik etme görevi, düzenleyici kurumların ortadan kaldırılması yerine, bu kurumların kalitesinin geliştirilmesine kaymıştır (Kelley, 2010: 542).

North ve Coase'un mülkiyet hakları ile kurumsal reform ihtiyacına yaptıkları vurguyu güçlendiren Perulu sosyal bilimci Hernando de Soto'ya göre de yoksul ülkeler, küreselleşmenin ekonomik dalgasına kapılarak yükselebilir ve düzenleyici kurumlarını, girişimcilerin piyasaya girişlerini engelleyen gereksiz bürokrasiyi ortadan kaldırmak veya en azından azaltmak üzere yeniden şekillendirerek yoksulluktan kurtulabilirler. Girişimciler gereksiz ve karmaşık düzenlemeler ile yasal gereklilikler nedeniyle yılmakta ve faaliyetlerini kayıt dışı (yeraltı) sektörlerde yürüterek basitçe karmaşadan kaçınmaktadırlar. Buna sebep olan unsur North ve Coase tarafından "işlem maliyeti" olarak tanımlanmaktadır. Girişimcilerin bahsedilen şekilde davranmaları sonucunda yalnızca müteşebbislerin ekonomik büyüme potansiyelleri değil aynı zamanda tüm ülke ekonomisi bundan zarar görecektir. North ve Coase'un teorileriyle tutarlı olarak De Soto'nun bu soruna ilişkin çözüm önerisi, daha iyi kurumların oluşturulması ve bu kurumların da özel mülkiyeti hayata geçirerek korumaları, mülk sahiplerinin atıl durumdaki sermayelerini yeniden canlandırarak varlıklarından artı değer yaratmalarına olanak tanımalarıdır (North, Coase ve De Soto'dan aktaran Kelley, 2010: 546, 547).

Ronald Coase, işlem maliyetlerinin olmadığ 1 bir durumda tarafların; dikey birleşme, mübadele, uzun vadeli sözleşmeler veya ürün özelliklerinin değiştirilmesi gibi yöntemlere başvurarak anlaşabileceklerini ifade eder. Coase, sıfır işlem maliyetini analiz için uygun bir başlangıç noktası olarak görmesine karşın pozitif işlem maliyetlerinin olduğu, gerçekte yaşadığımız dünyayı ele almamız gerektiğini ifade eder (Stigler ve Coase'dan aktaran Benham, 2008: 604).

Dolayısıyla işlem maliyetlerinin pozitif ve sınırlı olduğu görüşü yeni kurumsalcı yaklaşımı standart neo-klasik modelden ayrıştırmaktadır. Bu yaklaşım; bir bireyin karşı karşıya olduğu fiyatların, farklı tercihlerle ilişkili fırsat maliyetleri olduğuna ilişkin temel iktisadi öğretiden yararlanmaktadır. Veri bir mala ilişkin firsat maliyeti, bu malın fiyatı ile bu malı elde etmenin işlem maliyetini içermektedir. Piyasalar genellikle fiyatlardaki değişimler ile piyasada 
işlem gören malların diğer özelliklerinin birleşimiyle düzenlenmektedir. Bu özellikler arasında bölge, bekleme süresi, dayanıklılık, garanti, tazelik ve bunlarla ilişkili hizmetler yer almaktadır. Fiyatlar, yeni bir düzenlemeye yönelik olası tepkilerin tümünün değerlendirilmesinde eksik kalmaktadır. Malların ve mülkiyet haklarının nitelikleri, sözleşme şekilleri, organizasyonel yapı ve enformel bağlantıların hepsi yeni düzenlemeler karşısında değişiklik gösterebilir. Yeni düzenlemelere gösterilen tepkiler geleneksel olarak formel düzenlemelerle alakalı refah kayıplarını arttırabilir veya azaltabilir (Benham, 2008: 605).

\section{Rasyonel Tercih Kurumsalcılığı}

Rasyonel tercih yaklaşımının temel argümanı fayda maksimizasyonunun bireylerin öncelikli motivasyon kaynağı olduğu ve böyle olmaya da devam edeceğidir. Ancak bireyler hedeflerine en etkin biçimde ulaşmanın yolunun kurumsal faaliyetler olabileceğinin ve davranışlarının kurumlarca şekillendirildiğinin farkına varabilirler. $\mathrm{Bu}$ açıdan bakıldığında bireyler rasyonel biçimde ait oldukları kurum (hükümet) tarafından bir miktar sınırlandırılmayı tercih edebilirler. Örneğin aynı sektörde faaliyet gösteren rakiplerin davranışlarının da kısıtlanıyor olması bu seçimin belirleyicisi olabilir. Kurumların, sonuçların öngörülebilirliğini ve düzeni temin edebilmeleri de diğer bir tercih sebebi olarak gösterilebilir. Diğer taraftan kurumlar, bu yaklaşıma göre bireysel çıkarları peşinde koşanların sebep olduğu bedavacılık problemi gibi işlevsizliklerin önlenmesini de sağlayabilirler (Peters, 1999: 44-45).

Rasyonel tercih kurumsalcılığı, bağımsız idari otoritelerin kurulmasının zaman içerisinde ters seçim problemine, özellikle siyasi belirsizlikler ve güvenilir taahhüt konusunda çözüm olabileceğini varsayar. Buradaki güvenilir taahhüt kavramı kamulaştırmalara karşı ekonomik aktörlerin korunmasını ifade eder. Güvenilir taahhüt kapasitesinin yüksek olması, yatırımlar ve ekonomik büyümeye pozitif yönde etki edecektir (Gilardi, 2004: 69).

Bağımsız idari otoritelerin üstesinden gelebileceği diğer bir problem olan siyasi belirsizlikler, yetki veya güç devri ile bağlantılıdır. Kamu otoritesini kullanma hakkı, bir mülkiyet hakkı olarak düşünülebilir. Bu hak, politika ve yönetim yapısı tercihlerini belirlemek için kullanılmaktadır. Ancak ekonomiden farklı olarak demokratik bir sistemde bu mülkiyet hakları belirsizlik içerir. Çünkü bunlar periyodik olarak yeniden tahsis edilmektedir. Ayrıca bu yeniden tahsis sürecinde kaybedenlerin zararları tazmin de edilmemektedir. Dolayısıyla iktisadi aktörlerin mülkiyet hakları demokratik yönetimce korunurken, siyasi aktörlerinki ise demokratik yönetimin doğası sonucu korumasızdır. Sonuç olarak siyasi aktörlerin ilgileneceği 
ilk konu, eğer bunu yapma imkânları varsa, kendi mülkiyet haklarını güvenceye almak olacaktır. Böylece siyasi mülkiyet haklarındaki belirsizlik politik kurumların şekillendirilmesinde önemli bir rol oynar. Bu durum yasamanın, kontrol edemediği bürokrasiyi dizayn etmesine yol açabilir (Gilardi, 2004: 74).

Rasyonel tercih kurumsalcılı̆̆g, bilgi asimetrisinin yol açtığı sorunlardan biri olan asilvekil modelleri perspektifinden de ele alınmaktadır. $\mathrm{Bu}$ modeller organizasyonlarda uygulanabileceği gibi kamu sektöründeki kurumsal gruplar arasındaki etkileşimi anlamak amacına da hizmet edebilir. $\mathrm{Bu}$, özellikle de çok sayıda bağımsız düzenleyici komisyonun faaliyet gösterdiği Amerika Birleşik Devletleri’nde, düzenleyici politika analizinin standart bir aracı haline gelmiştir. Burada tanımlanan sorun; vekillerin, asilin isteklerini karşılamalarını garanti edecek bir yapının nasıl tasarlanacağıdır. Kullanılacak stratejilere özellikle bilgi asimetrisi probleminin üstesinden gelecek birtakım motivasyon araçları dahil edilerek ve denetim aracı kullanılarak vekillerin uyum göstermeleri sağlanabilir (Peters, 1999: 50-51). Bu yolla asil-vekil probleminin neden olduğu etkinsizlikler ortadan kaldırılarak işlem maliyetlerinin azaltılması mümkün olacaktır. Kurumsal sınırlandırmalar yoluyla asil ve vekillerin davranışlarının sınırlandırılması mümkün olabilir. Sonuçta asil ve vekillerin her zaman için kişisel çıkarlarını ön planda tutmalarının önüne geçilerek toplumsal hedeflere yönelmesi temin edilebilir (Delreux \& Adriaensen, 2017: 11-12).

\subsection{Sosyolojik Kurumsalcılık}

Sosyolojik kurumsalcılık, kurumların ahlaki değerler ve sosyal normları içeren unsurlar olduklarını ileri sürmektedir. Bu yaklaşım kurumların sosyal yaşama anlam kazandırdığını ifade etmekte ve bunu yaparken de kurumlar ve eylemler arasındaki etkileşime odaklanmaktadır (Alexander, 2005: 212).

Marx Weber'in teorik çalışmaları da kültürel değerlerin resmi kurumları etkileme ve şekillendirme biçimlerini ele almaktadır. Bu etkileme ve şekillendirme sürecinin meydana geldiği sosyo-ekonomik ve kültürel gelişmişlik düzeyinin bir önemi yoktur. Weber, kültürel değerler ile kurumların da dâhil olduğu toplumdaki formel yapılar arasında doğrudan bir bağın varlığını öne sürmektedir (Peters, 1999: 98).

Benzer şekilde ünlü Fransız Sosyolog Emile Durkheim da kurumların sosyal ve politik yaşamdaki rolünü ele almış ve sosyolojiyi "kurumlar bilimi” olarak adlandırmıştır. Durkheim 
ayrıca rasyonel kurumların gelişimiyle de ilgilenmiştir. Önceleri değerlerin rolü yerine daha çok objektif sosyal özelliklerin rolü ve özellikle de kurum ve kuruluşlardaki işbölümü ile alakadar olmuştur. Weber gibi Durkheim da sosyal güçler ile kurumların yapısı arasında bir bağ olduğunu söyler ancak aradaki nedensel bă̆ Durkheim'a, Weber'den daha yakın görünmektedir (Peters, 1999: 99).

Thelen ve Steinmo (1992)'ya göre ise kurumlar, çevrelerindeki değişikliklere bağlı olarak önem kazanabilirler (Thelen ve Steinmo'dan aktaran Koelble, 1995: 238). Sosyolojik kurumsalcılığa göre bağımsız düzenleyici otoritelere yetki veya güç devrinin temel açıklayıcı faktörü gerçekte yönetimlerin karşılıklı bağımlılıkla hareket etmeleridir. Diğer bir anlatımla yönetimler, bağımsız bir düzenleyici kurumu oluşturmaya karar vermeden önce diğer yönetimlerin davranışlarını gözlemlemektedirler. $\mathrm{Bu}$ açıklamalara göre Sosyolojik kurumsalc1lık bir diffüzyon (nüfuz etme) perspektifine oturtulabilir. Nüfuz etme süreci ise Bayesyen öğrenme mekanizmasıyla açıklanabilir. Buna göre yönetimler, veri bir politikanın sağlayacağı faydaları değerlendirirken diğerlerinin bu konuda yaşadıkları deneyimleri dikkate almaktadırlar (Gilardi, 2004: 75-76). Sonuç olarak başlangıçta bir politikanın faydalı olamayacağına ilişkin inanışlar, diğer kurumların pozitif etki doğuran benzer politika uygulamalarının gözlemlenmesiyle değişiklik gösterebilecektir.

\subsection{Tarihsel Kurumsalcılık}

Regülasyon çalışmalarında çoğunlukla amaç bu regülasyonun etkisini, buna yönelik ortaya çıkabilecek çok çeşitli tepkileri ve bunun zaman içerisinde nasıl sonuç vereceğini anlamaktır. Konuyla ilgili olarak yeni kurumsalcı iktisat yaklaşımı tarihin, patika bağımlılığının, bireyler, firmalar ve ülkeler arasındaki deneyimsel farklılıkların rolünü dikkate almaktadır (Benham, 2008: 606).

Regülasyona ilişkin standart yazında genellikle tarihin ve patika bağımlılığının oynadığ rol göz ardı edilmiştir. Ancak tarihsel deneyimler yazılı ve yazılı olmayan kuralların oluşumu ve evriminin yanı sıra herhangi bir yeni düzenlemenin sonuçları bakımından da hayati öneme sahiptir. Regülasyonda patika bağımlılığı söz konusudur ve bu büyük ölçüde politik süreç ile tarihi ya da geçmiş deneyimlere dayanmaktadır. Ülkeler bu deneyimler bakımından ve norm ile gelenekler bakımından farklılıklar göstermektedirler. Zaman içerisindeki herhangi bir noktada yazılı kurallar, yazılı olmayan kurallar ve bunların uygulama karakteristikleri ülkeden ülkeye farklılık göstermektedir. Yeni bir formal düzenlemenin etkisi ve buna yönelik tepkiler ilgili 
ülkedeki bahsedilen etmenlerden ve bunların tarihi kalıplarından etkilenecektir (Benham, 2008: $600)$.

Tarihsel kurumsalcılık bağımsız idari otoritelerin kurulmasına yönelik fonksiyonel baskıya vurgu yapar (Gilardi, 2004: 69). Küreselleşme hareketi kapsamında gerçekleştirilen regülasyon reformları büyük ölçüde ulusal kurumlar tarafından yönlendirilen baskıların bir sonucudur. Diğer bir deyişle değişim köklü ve farklı kurumlarca gerçekleştirilmiştir ve bu temellendirme de açıkça patika bağımlılığı argümanını vücuda getirir. Patika bağımlılığı perspektifinden bakıldığında devlet gelenekleri ve yapısı bu kurumların oluşturulmasında etkili olan en önemli faktörlerdir. Bağımsız düzenleyici otoritelerin en basit biçimde Birleşik Krallık’ta kurulabilmesi, tarihi ondokuzuncu yüzyıla dayanan ve demiryollarında karşımıza çıkan düzenleyici kurulların gelenekleri ile mümkün olmuştur. Diğer taraftan Fransa'da devletin birliğine yönelik endişeler bağımsız düzenleyici otoritelerin kurulmasında uzunca bir süre engel teşkil etmiştir (Gilardi, 2004: 81).

Tarihsel kurumsalcıların üzerinde durdukları bir konu, gücün kurumlar tarafindan sosyal gruplar arasında nasıl dağıtıldığıdır. Bu dağıtım yollarını ele alırken bireylerin özgürce sözleşme yapabildikleri bir durum yerine, kurumların, karar verme sürecine katılmak bakımından bazı gruplara daha fazla imkân tanıdığı bir durumu ele alırlar. Aynı şekilde herkesi daha iyi bir duruma getirecek bir sonuç üzerine vurgu yapmak yerine bazı gruplar kaybederken diğerlerinin nasıl kazandıkları üzerinde dururlar. Örneğin Steinmo (1993), ülkeler arasındaki vergi politikası farklılıklarının büyük oranda politik kurumların, politik süreçte temsil edilmesi en olası toplumsal çıkarları yapılandırma şekillerinden kaynaklandığını ifade etmektedir. Amerikan ekonomisine yönelik olarak Weir (1992), diğerlerine karşı bazı sosyal koalisyonların oluşturulmasında politik sistemin yapısının nasıl etkili olduğunu göstermiştir (Steinmo ve Weir'den aktaran Hall ve Taylor, 1996: 941).

\subsection{Söylemsel Kurumsalcılık}

"En yeni" yeni kurumsalcılık olarak ifade edilen söylemsel kurumsalcılık (discursive institutionalism) yaklaşımından da söz edilmelidir. Bu yaklaşım, siyasi davranışlara ilişkin düşünceler üretme, planlama veya meşrulaştırma süreçleriyle ilgilenen aktörlerin söylemlerini göz önüne almaktadır. Schmidt, bu söylemsel kurumsalcılık kavramını siyaset biliminde düşüncelerin asli (maddi) içeriklerini hesaba katan çok çeşitli çalışmaya ve bu düşüncelerin ortaya çıkmasına hizmet eden interaktif söylemler ile bu düşüncelerin kamuyla paylaşı1ma 
sürecine ilişkin bir şemsiye kavram olarak kullanmaktadır. Bu en yeni kurumsalcılık türü diğer kurumsalcı görüşlerdekine benzer biçimde kurumların önemi üzerinde durmaktadır. Ancak politik faaliyetleri algılayışımızın gelişimine katkıda bulunması bakımından diğer yeni kurumsalcılık yaklaşımlarından ayrılmaktadır (Schmidt, 2008: 305; Schmidt, 2011: 47-48). Örneğin kurumları açıklarken rasyonel tercih kurumsalcılığı rasyonel davranışlar ve çıkarları, tarihsel kurumsalcılık tarihsel kurallar ve düzenlemeleri, sosyolojik kurumsalcılık kültürel norm ve yapıyı esas alırken söylemsel kurumsalcılık düşünceler ve söylemleri esas almaktadır.

Panizza ve Miorelli (2013) PSDT'nin (post structuralist discourse theory), Schimidt'in söylemsel kurumsalcılığına katkı sağlayabileceğini ve kurumsal değişimi açıklamada faydalı olabileceğini ifade etmektedirler. PSDT’nin temelinde toplumun ilişki anlayışı yer almaktadır. PSDT, toplumu; söylemsel olarak oluşturulmuş, kurucu unsurları arasındaki anlamlı diferansiyel ilişkiler sistemi olarak görmektedir. PSDT, sosyal kuralların hiçbir zaman tamamen yapılandırılamayacağını, fakat politik müdahaleler ve değişikliklere açık olduğunu ve bu sebeple sosyal kuralların nihai bir oluşumunun gerçekleştirilmesinin olanaksız hale geldiğini söyler (Panizza ve Miorelli, 2013: 301-302).

Söylemsel yetenekler kurumsal değişimin açıklanması için gereklidir. Çünkü insanlar kurumlar dışında da eylemlerine devam etmektedirler. Bu kurumlar hakkında eleştirel söylemlerde bulunmak, onlarla iletişim kurmak ve bunlara yönelik tartışmalar yapmak, kurumları hakkındaki düşünceleri değiştirmek üzere hem kendilerini hem de başkalarını ikna etmek ve daha sonra bunları değiştirmek için harekete geçmek (söylemci koalisyonlar veya halkı bilgilendirmek yoluyla), insanların düşünme yeteneklerine işaret etmektedir. Faydalı politikaların ikna edici bir dille aktarılması siyasi aktörlerin seçim kazanmasını ve fikirlerini uygulayabileceği yetkileri elde etmesini kolaylaştıracaktır (Schmidt, 2010: 16).

Schmidt (2010), gelişmiş ekonomilerde finansal piyasaların ve ekonomilerin nasıl çöktüğünü, bir ülkenin neo-liberalizmden müdahaleciliğe nasıl bir anda geçiş yaptığını veya liberalizasyon, özelleştirme ve deregülasyonun bir sonucu olarak savaş sonrası kapitalizm çeşitliliğindeki muazzam değişimin nasıl ortaya çıktığını açıklamaktadır. Bunu yaparken, piyasaları ve refah devletini yapılandıran ve yeniden inşa eden siyasi aktörlerin fikir ve söylemsel etkileşimlerini göz önünde bulundurmaktadır. Schmidt'e göre ana akım karşılaştırmalı politik ekonomide eksik olan nokta, kurumsal değişim ve sürekliliğe ilişkin dinamiklerin açıklanmasına, siyasi ekonomik aktörlerin neden, nasıl ve ne zaman makro-tarihi 
kurumlarını yeniden şekillendireceklerini ve stratejik çıkarlarını yeniden tanımlayacaklarını analiz edememesidir. Bu eksikliği ortadan kaldıracak olan ise söylemsel kurumsalcılıktır (V.A. Schmidt, 2010: 2).

Söylemsel kurumsalcılık, tarihsel kurumsalcılığın mekanik patika bağımlılığı yerine koşullar, ihtiyaçlar ve siyaset değiştikçe izlenecek patikanın da yeniden yorumlanarak değerlendirilebileceğini vurgulamaktadır. Dolayısıyla bu yaklaşımda evrimsel bir süreç söz konusudur.

\section{Sonuç}

Eski çağlardan itibaren toplumlar, kendilerini şekillendirecek ve yön verecek kurumlara ihtiyaç duymuşlardır. İktisadi faaliyetlerin yoğunlaşmasıyla birlikte bu ihtiyaç daha da artmış ve aynı zamanda bu kurumların yükleneceği sorumluluklarda da bir takım değişiklikler ortaya çıkmıştır. İktisadi faaliyetlerdeki artış yanında sanayileşme hamlelerinin yoğunlaşması ve ek olarak demokratikleşme hareketlerinin çoğalması da bu değişimde rol oynamıştır.

$\mathrm{Bu}$ süreç içerisinde iktisadi alandaki devlet faaliyetleri sürekli olarak tartışılmış ve iktisadi teoriler de bu tartışmalar etrafinda şekillenmiştir. İlgili kapsamda tartış1lan yaklaşımlardan biri de ekonomik performansı büyük ölçüde kurumsal tasarıma bağlayan kurumsalcı yaklaşımdır. Kurumsalcı yaklaşım tek bir düşünce tarzını ifade etmemiş ve öne sürülen argümanların farklılık göstermesi, iktisadi başarımda etkili olan farklı etkenlere vurgu yapan türlü düşüncelerin oluşumuna neden olmuştur.

Ortaya atılan farklı yaklaşımlardan birisi yeni kurumsalcı yaklaşımdır. Yeni kurumsalcılık içinde değerlendirilen dört farklı yaklaşımın, düzenleme ve düzenleyici kurumlara ilişkin düşünceleri bu çalışmanın konusunu oluşturmuştur. Bunlardan rasyonel tercih kurumsalcılığı, bağımsız idari otoritelerin güvenirlik ve siyasi belirsizlik sorunlarına çözüm olabileceğini ifade etmektedir. Sosyolojik Kurumsalcılık, kurumların şekillenmesinde kültürel değerler ile sosyal olguların ve yönetimler arası bağımlılığın etkili olduğunu öne sürmektedir. Tarihsel Kurumsalcılık, patika bağımlılığının ve geçmiş tecrübelerin önemini vurgulamaktadır. Söylemsel kurumsalcılık ise siyasiler ve politik iktisatçıların zaman içerisindeki fikri değişimlerinin kurumların şekillenmesinde önem arz ettiğini savunmaktadır.

Hangi yaklaşıma yakın olursa olsun kurumsal yapının bireylere firsat eşitliği sağlaması, teknolojik ilerlemelere ayak uydurabilmesi, politik çıkarları dışlaması, özel mülkiyet haklarını yasalarla güvence altına alması, iktisadi faaliyetlerin özgürce ve mümkün olduğunca az sayıda 
bürokratik aşamadan geçerek gerçekleştirilebilmesi vb. koşulları sağlaması durumunda iktisadi faaliyet, girişimcilik ve yatırımların artışıyla birlikte ülkelerin ekonomik performansı pozitif şekilde etkilenecektir.

\section{Kaynakça}

Alchian, A. A. (1979). Some Implications of Recognition of Property Right Transactions Costs. In K. Brunner (Ed.), Economics and Social Institutions Insights from the Conferences on Analysis and Ideology (1st ed., pp. 233-254). New York: The Center for Research in Government Policy and Business.

Alchian, A. A., \& Demsetz, H. (1973). The Property Right Paradigm. The Journal of Economic History, 33(1), 16-27.

Alexander, E. R. (2005). Institutional transformation and Planning: From Institutionalization Theory to Institutional Design. Planning Theory, 4(3), 209-223.

Ayres, C. E. . (1951). The Co-Ordinates of Institutionalism. The American Economic Review, 41(2), 47-55.

Benham, L. (2008). Licit and Illicit Responses to Regulation. In C. Menard \& M. M. Shirley (Eds.), Handbook of New Institutional Economics (pp. 591-608). Heidelberg: Springer.

Carrigan, C., \& Coglianese, C. (2011). The Politics of Regulation: From New Institutionalism to New Governance. Annual Review of Political Science, 14(1), 107-129.

Delreux, T., \& Adriaensen, J. (2017). Introduction. Use and Limitations of the Principal--Agent Model in Studying the European Union. In T. Delreux \& J. Adriaensen (Eds.), The Principal Agent Model and the European Union (pp. 1-34). Cham: Springer International Publishing.

Eroğlu, Y. M. (2018). Kurumsal İktisatta Aç1lan Yeni Bir Pencere: Douglass C. North Perspektifinden Kurumların Değerlendirilmesi. Optimum Ekonomi ve Yönetim Bilimleri Dergisi, 5(2), 163-178.

Fligstein, N. (1991). The Structural Transformation of American Industry: An Institutional Account of the Causes of Diversification in the Largest Firms, 1919-1979. In W. W. Powell \& P. J. DiMaggio (Eds.), The New Institutionalism in Organizational Analysis (pp. 311-336). Chicago: The University of Chicago Press.

Gilardi, F. (2004). The Politics of Regulation. (J. Jordana \& D. Levi-Faur, Eds.). Cheltenham: Edward Elgar Publishing. 
Hall, P. A., \& Taylor, R. C. R. (1996). Political Science And The Three New Institutionalisms. Political Studies, 44(5), 936-957.

Jensen, M. C., \& Meckling, W. H. (1979). Economics and Social Institutions Insights from the Conferences on Analysis and Ideology. In K. Brunner (Ed.), Economics and Social Institutions Insights from the Conferences on Analysis and Ideology (1st ed., pp. 163-232). New York: The Center for Research in Government Policy and Business.

Karakurt, B. (2011). Washington Konsensüsü'nden Küresel Mali Krize Mali Disiplin ve Türkiye'deki Gelişmeler. Atatürk Üniversitesi İktisadi ve İdari Bilimler Dergisi, 25(1), $31-53$.

Kelley, T. (2010). Beyond the Washington Consensus and New Institutionalism: What is the Future of Law and Development? North Carolina Journal of International Law \& Commercial Regulation, 35(3), 539-554.

Koelble, T. A. (1995). The New Institutionalism in Political Science and Sociology. Comparative Politics, 27(2), 231-243.

Mueller, D. (2003). Public Choice III. New York: Cambridge University Press.

North, D. C. (2010). Kurumlar, Kurumsal Değişim ve Ekonomik Performans (2nd ed.). İstanbul: Sabancı Üniversitesi.

Olson, M. (1982). The Rise and Decline of Nations: Economic Growth, Stagflation, and Social Rigidities. New Haven: Yale University Press.

Panizza, F., \& Miorelli, R. (2013). Taking Discourse Seriously: Discursive Institutionalism and Post-structuralist Discourse Theory. Political Studies, 61(2), 301-318.

Peters, B. G. (1999). Institutional Theory In Political Science: The "New Institutionalism" (1st ed.). London: Pinter.

Rutherford, M. (1994). Institutions in Economics: The Old and the New Institutionalism. (C. D. Goodwin, Ed.). Cambridge: Cambridge University Press.

Schmid, A. A. (1981). Predicting the Performance of Alternative Institutions. In W. J. Samuels \& A. A. Schmid (Eds.), Law and Economics: An Institutional Perspective (pp. 76-94). Dordrecht: Springer Netherlands.

Schmidt, V. A. (2008). Discursive Institutionalism: The Explanatory Power of Ideas and Discourse. Annual Review of Political Science, 11(1), 303-326.

Schmidt, V. A. (2010). Taking Ideas and Discourse Seriously: Explaining Change Through Discursive Institutionalism as the Fourth 'New Institutionalism.' European Political 
FSECON DiBO, M. (2019), "Yeni Kurumsalcı Bakış Açısından Düzenlemeler ve Düzenleyici Otoriteler", Fiscaoeconomia, Vol.3(3), 26-41.

Science Review, 2(1), 1-25.

Schmidt, V. A. (2011). Reconciling Ideas and Institutions through Discursive Institutionalism.

In D. Beland \& H. R. Cox (Eds.), Ideas And Politics In Social Science Research (pp. 4764). New York: Oxfor University Press. 